Supplement of Earth Surf. Dynam., 3, 483-499, 2015

http://www.earth-surf-dynam.net/3/483/2015/

doi:10.5194/esurf-3-483-2015-supplement

(C) Author(s) 2015. CC Attribution 3.0 License.

(c) (i)

Supplement of

\title{
Topographic roughness as a signature of the emergence of bedrock in eroding landscapes
}

\section{T. Milodowski et al.}

Correspondence to: D. T. Milodowski (d.t.milodowski@ed.ac.uk)

The copyright of individual parts of the supplement might differ from the CC-BY 3.0 licence. 

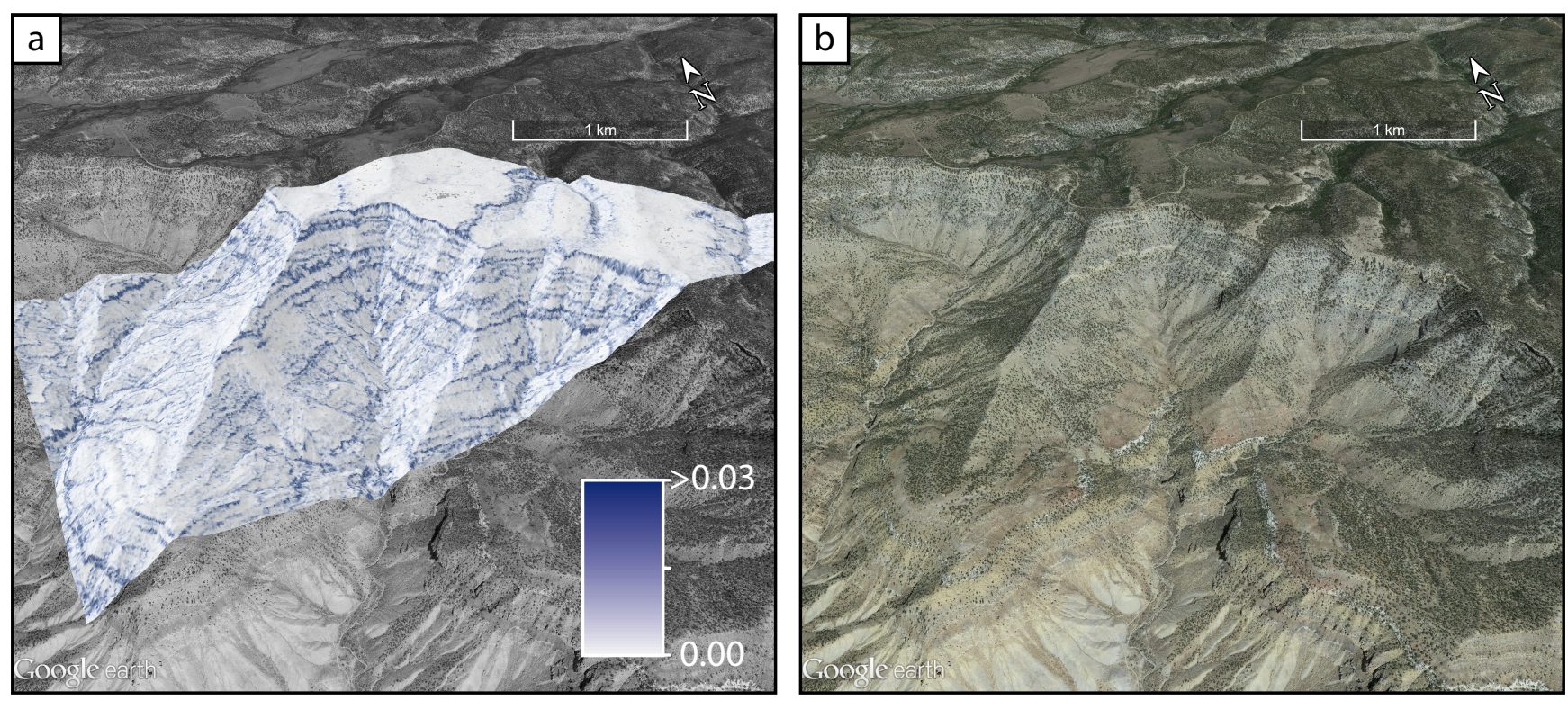
Figure S1. An illustration of the surface roughness algorithm introduced in this manuscript for a landscape underlain by layered sedimentary rock. The site is located on the Roan Plateau, Colorado, North of Grand Junction, and is underlain by Cretaceous to Tertiary sedimentary rock. The surface roughness picks out resistant beds that form bedrock outcrops through the steep scree-mantled slopes. LiDAR data acquisition and processing completed by the National Center for Airborne Laser Mapping (NCALM - http://www.ncalm.org); the data is freely available to download from the NSF OpenTopography service (http://opentopo.sdsc.edu/). Imagery courtesy of Google Earth. 